\title{
Vitamin D Status in Migraine Patients: A Case-Control Study
}

\author{
Alireza Zandifar, ${ }^{1,2}$ Samaneh sadat Masjedi, ${ }^{2}$ Mahboobeh Banihashemi, ${ }^{2}$ \\ Fatemeh Asgari, ${ }^{2}$ Navid Manouchehri, ${ }^{2}$ Homa Ebrahimi, ${ }^{3}$ \\ Faraidoon Haghdoost, ${ }^{1,2}$ and Mohammad Saadatnia ${ }^{1,4}$ \\ ${ }^{1}$ Physiology Research Center, Department of Physiology, Isfahan University of Medical Sciences, Isfahan 81745-319, Iran \\ ${ }^{2}$ Medical Student Research Center, Isfahan University of Medical Sciences, Isfahan 81745-319, Iran \\ ${ }^{3}$ Medical Student Research Center, Faculty of Medicine, Islamic Azad University, NajafAbad Branch, NajafAbad 8514143131, Iran \\ ${ }^{4}$ Department of Neurology and Isfahan Neurosciences Research Center, Isfahan University of Medical Sciences, Hezarjarib Avenue, \\ Isfahan 81745-319, Iran
}

Correspondence should be addressed to Mohammad Saadatnia; mosaadatnia@yahoo.com

Received 4 August 2013; Revised 10 October 2013; Accepted 16 October 2013; Published 2 January 2014

Academic Editor: Alessandro Landi

Copyright (C) 2014 Alireza Zandifar et al. This is an open access article distributed under the Creative Commons Attribution License, which permits unrestricted use, distribution, and reproduction in any medium, provided the original work is properly cited.

\begin{abstract}
Background. There have been few studies on the relation between vitamin D and migraine. We investigated the prevalence of vitamin $\mathrm{D}$ deficiency in migraine patients and compared it with a control group. We also evaluated the relationship of vitamin D deficiency with severity of migraine. Methods. 105 newly diagnosed migraine patients and 110 controls, matched for age, sex, socioeconomic status, education, and sun exposure, were enrolled during the spring of 2011. 25-Hydroxy vitamin D [25(OH)D] plasma levels were measured by chemiluminescence immunoassay. Results. The mean \pm SE concentration of $25(\mathrm{OH}) \mathrm{D}$ was $13.55 \pm 0.91 \mathrm{ng} / \mathrm{mL} \mathrm{in}$ cases and $13.19 \pm 1.19 \mathrm{ng} / \mathrm{mL}$ in controls. There was no significant difference in $25(\mathrm{OH}) \mathrm{D}$ concentration between cases and controls. We found no relationship between severity of headache and $25(\mathrm{OH}) \mathrm{D}$ status. Conclusions. We did not find any association between migraine and vitamin D status; also, severity of headaches was not related to $25(\mathrm{OH}) \mathrm{D}$ level. Further studies with larger sample sizes are required to confirm our results.
\end{abstract}

\section{Introduction}

Vitamin D deficiency is a global public health issue. Prevalence of vitamin D deficiency is about 30 to $50 \%$ in normal populations especially in young women $[1,2]$. Despite high sun exposure in middle eastern countries, these countries are among the areas with high prevalence of vitamin D deficiency in the world [3]. Vitamin D is not only important in mineral homeostasis but it is also an anti-inflammatory hormone that can regulate immune responses, cell proliferation, and endothelial function $[4,5]$. Also, vitamin $\mathrm{D}$ has a negative effect on proliferation of mast cells and can stimulate nitric oxide (NO) [6] (a vasoactive substance that interacts with blood vessels).

With these mechanisms, vitamin $\mathrm{D}$ has a potent role in cardiovascular disease [7]. Growing but conflicting evidence has shown a possible relationship between vitamin $\mathrm{D}$ and chronic or recurrent painful conditions such as migraine [8].
Migraine is a common hereditary chronic neurovascular disorder, characterized by dysfunction of the autonomic nervous system. In some patients, it has been accompanied by nausea and vomiting with phonophobia, photophobia, and osmophobia [9]. Migraine afflicts $18 \%$ of women and $6 \%$ of men and has a peak incidence in ages between 25 and 55 [10]. There is growing evidence for a role of endothelial dysfunction in migraine pathophysiology which suggests that migraine is attributed to vascular smooth muscle dysfunction [11].

Hypersensitivity of migraine patients' arteries to vasoactive substance such as NO can be a cause of dysfunction [12]. A number of studies have suggested that migraine attacks increase in cold seasons and higher latitude which may be related to lower vitamin D serum level [13].

One study reported that $40 \%$ of migraine patients had vitamin D deficiency [14]. Two case-report studies have shown that treatment with vitamin $\mathrm{D}$ and calcium in patients 
suffering from migraine dramatically reduced frequency and severity of migraine $[15,16]$. Improvement of headache symptoms in eight vitamin D insufficient patients that had osteomalacia and tension-type headache (TTH) symptoms has been reported after they took vitamin $\mathrm{D}$ and calcium supplements for a short period of time [17]. In molecular level, Motaghi et al. have shown that vitamin D receptor polymorphisms are associated with migraine without aura and also headache severity [18].

However, there are no studies that compare vitamin D levels between control group and migraine patients with a large enough sample size and adjustments for age and sex. Also, there are no studies that compare the frequency and severity of headaches based on the vitamin D status. Therefore, we investigated prevalence of vitamin D deficiency in migraine patients and compared it with a control group. We also evaluated vitamin $\mathrm{D}$ deficiency in relation to severity of migraine.

\section{Methods and Materials}

2.1. Study Design. We conducted a case-control study in the spring of 2011 from April to June. We selected the sample group from patients referred to neurology clinic in Alzahra hospital in Isfahan, Iran (32_390 north, 51_430 East, and $1475 \mathrm{~m}$ above sea).

Patients' diagnosis was based on ICHD-II diagnostic criteria [19]. 73 patients aged between 15 and 65 years, with newly diagnosed migraine, were consecutively enrolled. Use of vitamin D supplements, drugs with known effect on serum concentrations of 25-hydroxy vitamin D [25(OH)D], and specific prophylactic drugs such as Triptans and history of rheumatologic, gastrointestinal, liver, and kidney dysfunctions were defined as exclusion criteria. A control group of 98 people was selected from the patients' family members with no history of migraine that was matched for age, education, sex, sunlight exposure, and socioeconomic status. Informed consent was obtained from the participants before entering the study. The study was approved by the Ethics Committee of Isfahan University of Medical Sciences.

2.2. Data Collection and Measurement. Demographic data including age, sex, duration of sun exposure, place of residence, and level of education was obtained from both groups. Patients were evaluated with regard to their headache duration and headache frequency and filled out the migraine severity scale (MIGSEV). The MIGSEV was developed by EL Hasnaoui in 2003; it is a simple severity scale with four items including intensity of pain, disability in daily activities, tolerability, and nausea which categorizes patients in three groups of intensity; mild, moderate, and severe. This instrument is highly reliable, reproducible, and sensitive [20]. Persian translation of MIGSEV has been used in another study as a valid scale [21]. Women were asked about menstrual aggravating effects on headaches. Five $\mathrm{mL}$ of venous blood was drawn from each participant and immediately centrifuged. Serum samples were then frozen and kept at minus 70 degrees centigrade. Then, samples were
TABLE 1: Characteristics of case and control.

\begin{tabular}{|c|c|c|}
\hline Characteristic & Cases & Controls \\
\hline Sample size $(n)$ & 105 & 110 \\
\hline Age $($ mean $\pm \mathrm{SD})$ & $33.59 \pm 0.97$ & $32.46 \pm 0.91$ \\
\hline \multicolumn{3}{|l|}{ Age groups } \\
\hline$<30.5$ years & $50(47.6 \%)$ & $58(52.7 \%)$ \\
\hline$\geq 30.5$ years & $55(52.4 \%)$ & $52(47.3 \%)$ \\
\hline \multicolumn{3}{|l|}{ Sex } \\
\hline Female & $80(76.2 \%)$ & $89(80.9 \%)$ \\
\hline Male & $25(23.8 \%)$ & $21(19.1 \%)$ \\
\hline \multicolumn{3}{|l|}{ Place of residence } \\
\hline Urban & $52(49.5 \%)$ & $58(52.7 \%)$ \\
\hline Rural & $53(50.5 \%)$ & $52(47.3 \%)$ \\
\hline \multicolumn{3}{|l|}{ Level of education } \\
\hline $\begin{array}{l}\text { Below high } \\
\text { school diploma }\end{array}$ & $44(41.9 \%)$ & $44(40.0 \%)$ \\
\hline $\begin{array}{l}\text { Above high } \\
\text { school diploma }\end{array}$ & $61(58.1 \%)$ & $66(60.0 \%)$ \\
\hline $\begin{array}{l}\text { Duration of sun } \\
\text { light exposure } \\
\text { (mean } \pm \text { SE) }\end{array}$ & $98.14 \pm 6.54 \mathrm{~min} /$ day & $94.51 \pm 8.93 \mathrm{~min} /$ day \\
\hline \multicolumn{3}{|l|}{$\begin{array}{l}\text { Groups of sun light } \\
\text { exposure }\end{array}$} \\
\hline $0-120 \mathrm{~min} /$ day & $83(79.0 \%)$ & $90(81.8 \%)$ \\
\hline$\geq 120 \mathrm{~min} /$ day & $22(21.0 \%)$ & $20(18.2 \%)$ \\
\hline
\end{tabular}

measured for plasma levels of 25-hydroxy vitamin D using a chemiluminescent immunoassay kit (" $25 \mathrm{OH}$ Vitamin D total assay, Diasorin Liaison") by LIAISON analyzer. Based on previous studies and reports of Institute Of Medicine (IOM), we considered serum levels of 25-hydroxy vitamin $\mathrm{D}$ of $>20$, $10-20$, and $<10 \mathrm{ng} / \mathrm{mL}$ as normal, insufficient, and deficient, respectively [22].

2.3. Data Analysis. We analyzed our data with the SPSS software (version 18.0, Chicago, IL, USA). Mann-Whitney $U$ test was used for the comparison of quantitative variables between two groups and the Kruskal-Wallis test was used to compare mean of $25(\mathrm{OH}) \mathrm{D}$ between multiple groups, since our data was not normally distributed. The relationships between vitamin $\mathrm{D}$ status (mild, moderate, or severe deficiency) and different categorized variables (age, sex, casecontrol) were investigated using the Chi-square test and the calculation of odds ratios with $95 \%$ confidence intervals ( $95 \%$ CI). The sample size achieved $80 \%$ of the statistical power. A two-tailed $P$ value of less than 0.05 was considered statistically significant.

\section{Results}

One hundred and five cases and 110 controls that were matched for age, sex, duration of sun exposure, area of residency, and level of education were enrolled in the study. Demographic data are presented in Table 1. 
The mean \pm SE concentration of vitamin $\mathrm{D}$ was $13.55 \pm$ $0.91 \mathrm{ng} / \mathrm{mL}$ in cases and $13.19 \pm 1.19 \mathrm{ng} / \mathrm{mL}$ in controls. There was no significant difference in the vitamin $\mathrm{D}$ concentration between cases and controls. The prevalence of normal, insufficient, and deficient vitamin D levels was $20 \%, 34.3 \%$ and $45.7 \%$ in cases and $18.2 \%, 30 \%$ and $51.8 \%$ controls, respectively. Comparison between different groups of vitamin $\mathrm{D}$ deficiency revealed no relation between the severity of deficiency and the presence of disease.

Prevalence of different features of migraine in patients and vitamin D status in each category is shown in Table 2.

There were no significant relationships between vitamin D concentration and frequency of headaches per month, presence of nausea, positive family history of migraine, duration of headache, and headache aggravation with menstruation. Different states in each MIGSEV items (level of nausea, pain tolerability, intensity of pain, and level of disability) were not associated with significant differences in vitamin D concentrations. Also, there was no significant difference in vitamin D levels between different grades of MIGSEV.

Vitamin D status in different subgroups of sex, age, duration of daily sun exposure, place of residence, and education levels in both cases and controls is demonstrated in Table 3. Within both cases and controls, there was a significant difference between level of $25(\mathrm{OH}) \mathrm{D}$ in males and females $(P=0.046$ and $P=0.019$, resp.). No differences were found in level of $25(\mathrm{OH}) \mathrm{D}$ between cases and controls, when analyses were conducted separately for men and women. Subjects in cases and controls with less sun exposure had significantly lower $25(\mathrm{OH}) \mathrm{D}$ levels than subjects with more exposure to sun light $(P=0.004$ and $P=0.000$, resp.). There was no significant difference between cases and controls with the same daily sun light exposure. 25(OH)D levels were not significantly different in patients under the age of 25 compared to older patients $(P>0.05)$ and also there was no significant difference between patients under the age of 50 and older patients $(P>0.05)$. There were no significant differences between subjects from rural and urban areas in the level of $25(\mathrm{OH}) \mathrm{D}$.

\section{Discussion}

Based on our results, there was no significant difference in $25(\mathrm{OH}) \mathrm{D}$ plasma levels between cases and controls. Our analysis also did not show any relationship between $25(\mathrm{OH}) \mathrm{D}$ plasma levels and the severity of headaches among patients.

Vitamin D deficiency has been defined based on various references. In most of the studies, $25(\mathrm{OH}) \mathrm{D}$ plasma levels lower than $10 \mathrm{ng} / \mathrm{mg}$ are considered deficient [22], but defining the threshold for the levels of vitamin D insufficiency is a controversial issue $[23,24]$. IOM recommended the levels of $20 \mathrm{ng} / \mathrm{mL}$ ( $50 \mathrm{nmol} /$ liter) covering the requirements of at least $97.5 \%$ of the population and this critical level will be useful for clinicians for patients' management [22]. Also, most of the studies reported that high majority of complications related to low levels of vitamin D such as hypoparathyroidism, bone fractures, and multiple sclerosis are becoming at levels below $20 \mathrm{ng} / \mathrm{mL}$ [25]. In contrast,
TABLE 2: Prevalence of different features of migraine in patients and vitamin D status as sufficient level (more than $20 \mathrm{ng} / \mathrm{mL}$ ) and deficient level (less than $10 \mathrm{ng} / \mathrm{mL}$ ) in each category.

\begin{tabular}{|c|c|c|c|}
\hline \multirow[b]{2}{*}{ Item (Case) } & \multicolumn{2}{|c|}{ Vitamin D level (ng/mL) } & \multirow[b]{2}{*}{$P$ value } \\
\hline & $\begin{array}{c}\text { Less than } \\
10\end{array}$ & $\begin{array}{l}\text { More than } \\
20\end{array}$ & \\
\hline \multicolumn{4}{|l|}{$\begin{array}{l}\text { Frequency of } \\
\text { headache per month }\end{array}$} \\
\hline$\leq 15$ & $41(78.8 \%)$ & $17(81.0 \%)$ & \multirow{2}{*}{0.840} \\
\hline$>15$ & $11(21.2 \%)$ & $4(19.0 \%)$ & \\
\hline \multicolumn{4}{|l|}{ Nausea } \\
\hline Yes & $40(76.9 \%)$ & $14(66.7 \%)$ & \multirow{2}{*}{0.366} \\
\hline No & $12(23.1 \%)$ & $7(33.3 \%)$ & \\
\hline \multicolumn{4}{|l|}{ Family history } \\
\hline Positive & $38(73.1 \%)$ & $14(66.7 \%)$ & \multirow{2}{*}{0.584} \\
\hline Negative & $14(26.9 \%)$ & $7(33.3 \%)$ & \\
\hline \multicolumn{4}{|l|}{ Menstrual effect } \\
\hline Yes & $22(45.8 \%)$ & $11(73.3 \%)$ & \multirow{2}{*}{0.063} \\
\hline No & $26(54.2 \%)$ & $4(26.7 \%)$ & \\
\hline \multicolumn{4}{|l|}{ Intensity of pain } \\
\hline Mild & $0(0.0 \%)$ & $0(0.0 \%)$ & \multirow{4}{*}{0.109} \\
\hline Moderate & $13(25.0 \%)$ & $5(23.8 \%)$ & \\
\hline Intense & $26(50.0 \%)$ & $15(71.4 \%)$ & \\
\hline Very Intense & $13(25.0 \%)$ & $1(4.8 \%)$ & \\
\hline \multicolumn{4}{|l|}{ Level of nausea } \\
\hline None & $12(23.1 \%)$ & $7(33.3 \%)$ & \multirow{4}{*}{0.148} \\
\hline Mild & $25(48.1 \%)$ & $4(19.0 \%)$ & \\
\hline Intense & $8(15.4 \%)$ & $5(23.8 \%)$ & \\
\hline Vomiting & $7(13.5 \%)$ & $5(23.8 \%)$ & \\
\hline \multicolumn{4}{|l|}{ Level of disability } \\
\hline None & $5(9.6 \%)$ & $2(9.5 \%)$ & \multirow{4}{*}{0.395} \\
\hline Mild & $24(46.2 \%)$ & $10(47.6 \%)$ & \\
\hline Marked & $10(19.2 \%)$ & $1(4.8 \%)$ & \\
\hline Confined to bed & $13(25.0 \%)$ & $8(38.1 \%)$ & \\
\hline \multicolumn{4}{|l|}{ Level of tolerability } \\
\hline Tolerable & $11(21.2 \%)$ & $4(19.0 \%)$ & \multirow{3}{*}{0.946} \\
\hline Barely tolerable & $28(53.8 \%)$ & $11(52.4 \%)$ & \\
\hline Intolerable & $13(25.0 \%)$ & $6(28.6 \%)$ & \\
\hline \multicolumn{4}{|l|}{ MIGSEV total } \\
\hline Low & $6(11.6 \%)$ & $4(19.0 \%)$ & \multirow{3}{*}{0.686} \\
\hline Intermediate & $23(44.2 \%)$ & $8(38.1 \%)$ & \\
\hline High & $23(44.2 \%)$ & $9(42.9 \%)$ & \\
\hline \multicolumn{4}{|c|}{ Duration of headache } \\
\hline $4-12 \mathrm{~h}$ & $24(46.2 \%)$ & $12(57.1 \%)$ & \multirow{3}{*}{0.695} \\
\hline $12-24 \mathrm{~h}$ & $16(30.8 \%)$ & $5(23.8 \%)$ & \\
\hline $24-72 \mathrm{~h}$ & $12(23.1 \%)$ & $4(19.0 \%)$ & \\
\hline
\end{tabular}

several references suggested the $25(\mathrm{OH}) \mathrm{D}$ plasma levels of $30 \mathrm{ng} / \mathrm{mL}$ as an optimal level of vitamin D [25]. Mithal et al. reported that the percentage of vitamin $\mathrm{D}$ insufficiency 
TABLE 3: Vitamin D status in different subgroups in both cases and controls.

\begin{tabular}{|c|c|c|c|c|c|}
\hline Item & $\begin{array}{l}\text { Mean of serum } \\
\text { vitamin } \mathrm{D} \pm \mathrm{SD} \\
\quad(\text { control })\end{array}$ & $\begin{array}{c}P \text { value } \\
\text { (within case groups) }\end{array}$ & $\begin{array}{l}\text { Mean of serum } \\
\text { vitamin } \mathrm{D} \pm \mathrm{SD} \\
(\text { case })\end{array}$ & $\begin{array}{c}P \text { value } \\
\text { (within control groups) }\end{array}$ & $\begin{array}{c}P \text { value } \\
\text { (between case and } \\
\text { control groups) }\end{array}$ \\
\hline \multicolumn{6}{|l|}{ Sex } \\
\hline Female & $11.84 \pm 1.34$ & \multirow{2}{*}{0.019} & $12.52 \pm 1.13$ & \multirow{2}{*}{0.046} & 0.702 \\
\hline Male & $18.91 \pm 2.19$ & & $16.82 \pm 1.15$ & & 0.381 \\
\hline \multicolumn{6}{|l|}{ Residency } \\
\hline Rural & $14.97 \pm 2.04$ & \multirow{2}{*}{0.159} & $15.12 \pm 1.19$ & \multirow{2}{*}{0.084} & 0.949 \\
\hline Urban & $11.60 \pm 1.30$ & & $11.94 \pm 1.37$ & & 0.857 \\
\hline \multicolumn{6}{|l|}{ Level of education } \\
\hline $\begin{array}{l}\text { Below high } \\
\text { school diploma }\end{array}$ & $13.00 \pm 1.68$ & \multirow[t]{2}{*}{0.895} & $13.08 \pm 1.26$ & \multirow[t]{2}{*}{0.672} & 0.967 \\
\hline $\begin{array}{l}\text { Above high } \\
\text { school diploma }\end{array}$ & $13.32 \pm 1.64$ & & $13.88 \pm 1.29$ & & 0.793 \\
\hline \multicolumn{6}{|l|}{$\begin{array}{l}\text { Duration of sun } \\
\text { exposure }\end{array}$} \\
\hline $0-120 \mathrm{~min} /$ day & $10.67 \pm 0.81$ & \multirow{2}{*}{0.000} & $12.20 \pm 1.01$ & \multirow{2}{*}{0.004} & 0.238 \\
\hline$\geq 120 \mathrm{~min} /$ day & $24.53 \pm 4.74$ & & $18.60 \pm 1.81$ & & 0.234 \\
\hline \multicolumn{6}{|l|}{ Group age } \\
\hline$\leq 25$ & $13.21 \pm 1.88$ & \multirow{2}{*}{0.993} & $12.21 \pm 1.95$ & \multirow{2}{*}{0.457} & 0.722 \\
\hline$>25$ & $13.18 \pm 1.49$ & & $13.90 \pm 1.04$ & & 0.693 \\
\hline$\leq 50$ & $12.85 \pm 1.21$ & \multirow{2}{*}{0.307} & $13.24 \pm 0.95$ & \multirow{2}{*}{0.243} & 0.803 \\
\hline$>50$ & $17.56 \pm 5.56$ & & $17.30 \pm 3.26$ & & 0.968 \\
\hline
\end{tabular}

The Mann-Whitney test was used to compare mean of vitamin D in different groups.

is high or very high in most European countries particularly elderly patients dependent on considering the required serum $25(\mathrm{OH}) \mathrm{D}$ level, either 20 or $30 \mathrm{ng} / \mathrm{mL}$, although, in some regions, such as South Asia and Middle East, vitamin D deficiency is very common in all age groups, from neonates to the elderly. For instance up to $70 \%$ of adolescent girls in Iran had 25(OH)D levels below $25 \mathrm{nmol} / \mathrm{L}$, consistent with findings in Saudi Arabia [24]. It looks that the $30 \mathrm{ng} / \mathrm{mL}$ level of vitamin D serum as a critical cut-point of defining vitamin $\mathrm{D}$ insufficiency would not be applicable to all regions in the world as there are other variables that affect the vitamin $\mathrm{D}$ status in different populations including mean age of the population, air pollution, nutritional status, socioeconomic status, regional latitude, and dietary vitamin $\mathrm{D}$ fortification [26].

Finally, it seems that prevalence of vitamin D inadequacy has been overestimated by considering inappropriate cutpoints such as serum $25(\mathrm{OH}) \mathrm{D}$ above $30 \mathrm{ng} / \mathrm{mL}$ as a normal level of vitamin D [22]. So, in the present study, we defined sufficient, insufficient, and deficient as $25(\mathrm{OH}) \mathrm{D}$ levels of more than 20, 10-20, and less than $10 \mathrm{ng} / \mathrm{mL}$, respectively.

The vitamin D plasma level can be measured by different laboratory methods including chemiluminescence assay, radioimmunoassay (RIA), and enzyme-linked immunosorbent assay (ELISA). Different methods can lead to significantly different reported levels of vitamin $\mathrm{D}$ in the same sample population. Intermethod variability of the $25(\mathrm{OH}) \mathrm{D}$ plasma levels can impact on further analysis of data from different studies. Data standardization is of great importance when different methods are used [27].

To our knowledge, this is the first case-control study that evaluates the status of vitamin $\mathrm{D}$ in patients with migraine headache. We did not find any significant difference in $25(\mathrm{OH}) \mathrm{D}$ plasma levels between cases and controls. A summary of studies on the relationship between vitamin $\mathrm{D}$ and headache (including design, sample size, type of headache, severity of headache assessment, mean vitamin D, and vitamin D measurement method) is shown in Table 4.

In a topical review, Straube et al. claimed that high quality evidence had not found any convincing relationship between chronic pain and vitamin D status [8]. Kjaergaard et al. in a cross-sectional study with a large sample concluded that vitamin $\mathrm{D}$ is not related to migraine. The latter, however, is limited as it has used a questionnaire to identify patients rather than identifying them clinically. Questionnaires may miss the patients or overdiagnose people with migraine. Also, in this study, the relationship between severity and frequency of headaches and vitamin D is not evaluated [28]. Our results did not show any relation between vitamin $D$ and either severity of the headaches or their frequency.

Some studies have suggested that higher latitudes are associated with more sever and frequent headaches and therefore can originate from lower $25(\mathrm{OH}) \mathrm{D}$ plasma levels due to diminished sun exposure. This conclusion, however, is not totally reliable as there are regions with lower latitudes and worse vitamin D status. It can be assumed that vitamin 
TABLE 4: Summary of the literature on relation between vitamin $\mathrm{D}$ and headache.

\begin{tabular}{|c|c|c|c|c|c|c|c|}
\hline $\begin{array}{l}\text { The first } \\
\text { author (year) }\end{array}$ & $\begin{array}{l}\text { Study } \\
\text { design }\end{array}$ & $\begin{array}{c}\text { Patient } \\
\text { sample size }\end{array}$ & $\begin{array}{l}\text { Type of } \\
\text { headache }\end{array}$ & $\begin{array}{l}\text { Headache } \\
\text { severity } \\
\text { assessment }\end{array}$ & $\begin{array}{l}\text { Methods of vitamin D } \\
\text { level assessment }\end{array}$ & $\begin{array}{l}\text { Mean of vitamin } \\
\text { D level in } \\
\text { patient }(\mathrm{ng} / \mathrm{mL})\end{array}$ & $\begin{array}{c}\text { Effect/association } \\
\text { of vitamin D } \\
\text { (found by authors) }\end{array}$ \\
\hline $\begin{array}{l}\text { Kjaergaard et } \\
\text { al. [28] } \\
(2012)\end{array}$ & $\begin{array}{l}\text { Cross- } \\
\text { sectional }\end{array}$ & 4061 & $\begin{array}{c}\text { Migraine } \\
(N=322) \\
\text { Nonmigraine } \\
\text { headache } \\
(N=3739)\end{array}$ & Yes & $\begin{array}{c}\text { Electrochemiluminescent } \\
\text { immunometric } \\
\text { assay }\end{array}$ & $\begin{array}{c}24.62 \\
\text { (migraine } \\
\text { patient) } \\
24.48 \\
\text { (nonmigraine } \\
\text { headache) }\end{array}$ & Not associated \\
\hline $\begin{array}{l}\text { Knutsen et al. } \\
{[33](2010)}\end{array}$ & $\begin{array}{l}\text { Cross- } \\
\text { sectional }\end{array}$ & 63 & $\begin{array}{l}\text { Patients with } \\
\text { chief complaint } \\
\text { of headache }\end{array}$ & Yes & $\begin{array}{l}\text { High-pressure liquid } \\
\text { chromatography } \\
\text { mass spectrometry } \\
\text { (HPLC-MS) }\end{array}$ & 14 & Associated \\
\hline $\begin{array}{l}\text { O’Brien et al. } \\
\text { [29] (2010) }\end{array}$ & $\begin{array}{l}\text { Cross- } \\
\text { sectional }\end{array}$ & 300 & $\begin{array}{c}\text { Episodic } \\
\text { migraine } \\
(N=173) \\
\text { Chronic } \\
\text { migraine } \\
(N=127)\end{array}$ & No & Not reported & $\begin{array}{c}24.19 \\
\text { (episodic } \\
\text { migraine) } \\
23.19 \text { (chronic } \\
\text { migraine) }\end{array}$ & Associated \\
\hline $\begin{array}{l}\text { Krusz et al. } \\
{[30](2010)}\end{array}$ & $\begin{array}{l}\text { Cross- } \\
\text { sectional }\end{array}$ & 100 & $\begin{array}{l}\text { Migraine/ } \\
\text { headache } \\
(N=34) \text { pain } \\
\text { syndromes } \\
(N=33)\end{array}$ & No & Not reported & $\begin{array}{c}29.3 \\
\text { (migraine/ } \\
\text { headache) } \\
28.2 \text { (pain } \\
\text { syndromes) }\end{array}$ & Not associated \\
\hline $\begin{array}{l}\text { Wheeler [14] } \\
(2008)\end{array}$ & $\begin{array}{l}\text { Cross- } \\
\text { sectional }\end{array}$ & 54 & $\begin{array}{l}\text { Chronic } \\
\text { migraine }\end{array}$ & No & Not reported & 34.6 & Associated \\
\hline $\begin{array}{l}\text { Prakash [17] } \\
(2009)\end{array}$ & $\begin{array}{l}\text { Case } \\
\text { report }\end{array}$ & 8 & $\begin{array}{l}\text { Chronic } \\
\text { tension-type } \\
\text { headache }\end{array}$ & No & Not reported & 7 & Effective \\
\hline $\begin{array}{l}\text { Thys-Jacobs } \\
{[15]} \\
\text { (November } \\
\text { 1994) }\end{array}$ & $\begin{array}{l}\text { Case } \\
\text { report }\end{array}$ & 2 & Migraine & Yes & Not reported & Not reported & Effective \\
\hline $\begin{array}{l}\text { Thys-Jacobs } \\
\text { [16] (October } \\
1994 \text { ) }\end{array}$ & $\begin{array}{l}\text { Case } \\
\text { report }\end{array}$ & 2 & $\begin{array}{l}\text { Menstrually- } \\
\text { related } \\
\text { migraines }\end{array}$ & Yes & Not reported & Not reported & Effective \\
\hline
\end{tabular}

D insufficiency may be caused by a multiple factors and latitude alone may not be responsible for lower $25(\mathrm{OH}) \mathrm{D}$ plasma levels. Seasonal changes in $25(\mathrm{OH}) \mathrm{D}$ plasma levels are reported in the literature [8].

Thys-Jacobs reported dramatic reduction in frequency and duration of headaches after supplemental vitamin D administration. However, these results were from small case reports in two premenopausal and two postmenopausal women without control group $[15,16]$. Despite these results we did not find any relation between $25(\mathrm{OH}) \mathrm{D}$ plasma levels and menstrual related aggravation of headaches. The therapeutic effect of vitamin D supplementation is thought to be due to higher absorption of magnesium; however, these treatments were accompanied by calcium supplements also and the results could be attributed to both vitamin D and calcium or even the synergetic effect of the treatment.

Wheeler suggested in his study that migraine and vitamin D could be associated as $40.7 \%$ of the patients in that study had vitamin D deficiency. The study is limited though, as the diagnostic criteria for migraine were not clear, the study did not have a matched control group and patients who received vitamin D supplements were not excluded [14]. O'Brien et al. also found a high prevalence of vitamin $\mathrm{D}$ deficiency among pediatric patients with recurrent headaches in their study [29]. In another study, Krusz et al. established that there were no significant differences in vitamin D levels between migraine patients and other patients with any other pain disorders [30]; however, the major limitation of these two studies was the lack of a control group.

Prakesh et al. reported positive effects of vitamin D and calcium supplements in tension type headache (TTH) patients. Beneficial outcomes of optimal 25(OH)D levels for TTH patients are also suggested by Keargaard et al. Prakash et al. reported high levels of parathyroid hormone (PTH) in migraine patients which could be due to secondary hyperparathyroidism that was treated by optimal levels of vitamin D supplement. The role of endothelial dysfunction and also the role of nitric oxide (NO) through vasodilatation as triggers for migraine headaches have been well established [11, 12]. There are also studies, claiming that there 
are higher levels of parathyroid hormone in the systemic circulation of patients with heart failure, which is associated with endothelial dysfunction [31]. Also, it is stated that PTH upregulates the activity of the endothelial nitric oxide synthase eNOS system through protein kinase pathways [32]. On the other hand, vitamin D deficiency can cause secondary hyperparathyroidism. However, whether or not the rise of PTH in this phenomenon contributes to worse migraine headaches through NO release and endothelial dysfunction is a matter of debate that needs further study.

Knutsen et al. stated that vitamin D status has a much stronger relationship with headache rather than either musculoskeletal pain or fatigue [33]. Our results did not reveal any relationship between the severity of the vitamin $\mathrm{D}$ deficiency and severity of the headaches. Also, 25(OH)D plasma levels were not different between MIGSEV items (nausea, intensity of pain, pain tolerability, and disability).

We found that, in both cases and controls, female patients had significantly lower levels of $25(\mathrm{OH}) \mathrm{D}$, but there was no difference in subjects of the same gender between cases and controls. Higher vitamin D deficiency and more severe pain in females have been reported in previous studies as well [8, 33].

The relationship between age and severity of vitamin D deficiency was established by Knutsen et al. [33]. We found no relation between the age and levels of $25(\mathrm{OH}) \mathrm{D}$. Also, according to our results, vitamin $\mathrm{D}$ level was not related to level of education and place of living (rural or urban).

The prevalence of vitamin D deficiency is roughly similar between cases and controls and between matching age groups. This suggests a high prevalence of vitamin D deficiency in both healthy population and migraine patients which implies a common underlying cause. It seems appropriate to conduct population-based observational studies to better assess the role of vitamin $\mathrm{D}$ in incidence, severity, and treatment of migraine headaches $[13,17]$.

There are some limitations to our study. Our criteria only included new cases of migraine headache; although this benefited the study since new migraine patients had no history of medication, it also led to a small sample size. Lack of body mass index (BMI) matching between cases and controls was another weakness of our study; however, we matched the patients and controls for sun exposure and subjects who received vitamin D supplements were excluded.

In conclusion, we did not find any association between migraine and vitamin D status; also, severity of headaches was not related to vitamin D level. Other studies with larger sample sizes and randomized double-blind clinical trials should be performed to confirm this hypothesis.

\section{Conflict of Interests}

All authors have read and approved the content of the paper. The authors declare no conflict of interests.

\section{Authors' Contribution}

Samaneh sadat Masjedi, Mahboobeh Banihashemi, Fatemeh Asgari, Navid Manouchehri, Homa Ebrahimi, and Faraidoon
Haghdoost contributed to data collection and analysis. They also contributed to drafting of the paper. Alireza Zandifar and Mohammad Saadatnia made substantial contributions to the conception and design of the study, analysis of the data, and drafting of the paper.

\section{Acknowledgment}

This study was supported by Isfahan University of Medical Sciences, Isfahan, Iran (Grant no. 290031). Authors would like to appreciate generous collaborations of Dr. Forough Sharifi (Manager of Dr. Sharifi Medical Lab, Isfahan, Iran) for her cooperation in laboratory testing.

\section{References}

[1] M. F. Holick, R. M. Biancuzzo, T. C. Chen et al., "Vitamin D2 is as effective as vitamin D3 in maintaining circulating concentrations of 25-hydroxyvitamin D," Journal of Clinical Endocrinology and Metabolism, vol. 93, no. 3, pp. 677-681, 2008.

[2] S. Hovsepian, M. Amini, A. Aminorroaya, P. Amini, and B. Iraj, "Prevalence of Vitamin D deficiency among adult population of Isfahan city, Iran," Journal of Health, Population and Nutrition, vol. 29, no. 2, pp. 149-155, 2011.

[3] J. Mytton, A. P. Frater, G. Oakley, E. Murphy, M. J. Barber, and S. Jahfar, "Vitamin D deficiency in multicultural primary care: a case series of 299 patients," British Journal of General Practice, vol. 57, no. 540, pp. 577-579, 2007.

[4] L. Adorini and G. Penna, "Control of autoimmune diseases by the vitamin D endocrine system," Nature Clinical Practice Rheumatology, vol. 4, no. 8, pp. 404-412, 2008.

[5] Y. Talmor, E. Golan, S. Benchetrit et al., "Calcitriol blunts the deleterious impact of advanced glycation end products on endothelial cells," American Journal of Physiology, vol. 294, no. 5, pp. F1059-F1064, 2008.

[6] E. Baroni, M. Biffi, F. Benigni et al., "VDR-dependent regulation of mast cell maturation mediated by 1,25-dihydroxyvitamin D3," Journal of Leukocyte Biology, vol. 81, no. 1, pp. 250-262, 2007.

[7] Y. Suzuki, T. Ichiyama, A. Ohsaki, S. Hasegawa, M. Shiraishi, and S. Furukawa, "Anti-inflammatory effect of $1 \alpha, 25-$ dihydroxyvitamin D3 in human coronary arterial endothelial cells: implication for the treatment of Kawasaki disease," Journal of Steroid Biochemistry and Molecular Biology, vol. 113, no. 1-2, pp. 134-138, 2009.

[8] S. Straube, R. Andrew Moore, S. Derry, and H. J. McQuay, "Vitamin D and chronic pain," Pain, vol. 141, no. 1-2, pp. 10-13, 2009.

[9] S. D. Silberstein, "Migraine," The Lancet, vol. 363, no. 9406, pp. 381-391, 2004.

[10] R. B. Lipton and W. F. Stewart, "Prevalence and impact of migraine," Neurologic Clinics, vol. 15, no. 1, pp. 1-13, 1997.

[11] R. Napoli, V. Guardasole, E. Zarra et al., "Vascular smooth muscle cell dysfunction in patients with migraine," Neurology, vol. 72, no. 24, pp. 2111-2114, 2009.

[12] F. H. Vanmolkot and J. N. De Hoon, "Endothelial function in migraine: a cross-sectional study," BMC Neurology, vol. 10, p. 119, 2010.

[13] S. Prakash, N. C. Mehta, A. S. Dabhi, O. Lakhani, M. Khilari, and N. D. Shah, "The prevalence of headache may be related with the 
latitude: a possible role of Vitamin D insufficiency?" The Journal of Headache and Pain, vol. 11, no. 4, pp. 301-307, 2010.

[14] S. Wheeler, "Vitamin D deficiency in chronic migraine," Headache, vol. 48, pp. S52-S53, 2008.

[15] S. Thys-Jacobs, "Alleviation of migraines with therapeutic vitamin D and calcium," Headache, vol. 34, no. 10, pp. 590-592, 1994.

[16] S. Thys-Jacobs, "Vitamin D and calcium in menstrual migraine," Headache, vol. 34, no. 9, pp. 544-546, 1994.

[17] S. Prakash and N. D. Shah, "Chronic tension-type headache with vitamin d deficiency: casual or causal association?" Headache, vol. 49, no. 8, pp. 1214-1222, 2009.

[18] M. Motaghi, S. Haghjooy Javanmard, F. Haghdoost et al., "Relationship between vitamin D receptor gene polymorphisms and migraine without aura in an Iranian population," BioMed Research International, vol. 2013, Article ID 351942, 6 pages, 2013.

[19] Headache Classification Subcommittee of the International Headache Society, "The International classification of headache disorders: 2nd edition," Cephalalgia, vol. 24, supplement 1, pp. 9-160, 2004.

[20] A. El Hasnaoui, M. Vray, A. Richard, F. Nachit-Ouinekh, and F. Boureau, "Assessing the severity of migraine: development of the MIGSEV scale," Headache, vol. 43, no. 6, pp. 628-635, 2003.

[21] A. Zandifar, S. S. Masjedi, F. Haghdoost et al., "The psychometric properties of the persian migraine-specific quality of life questionnaire version 2.1 in episodic and chronic migraines," The Scientific World Journal, vol. 2013, Article ID 950245, 6 pages, 2013.

[22] A. C. Ross, J. E. Manson, S. A. Abrams et al., "The 2011 report on dietary reference intakes for calcium and vitamin $\mathrm{D}$ from the Institute of Medicine: what clinicians need to know," Journal of Clinical Endocrinology and Metabolism, vol. 96, no. 1, pp. 53-58, 2011.

[23] C. J. Rosen, S. A. Abrams, J. F. Aloia et al., "IOM committee members respond to endocrine society vitamin D guideline," Journal of Clinical Endocrinology and Metabolism, vol. 97, no. 4, pp. 1146-1152, 2012.

[24] A. Mithal, D. A. Wahl, J.-P. Bonjour et al., "Global vitamin D status and determinants of hypovitaminosis D," Osteoporosis International, vol. 20, no. 11, pp. 1807-1820, 2009.

[25] M. F. Holick, "Medical progress: vitamin D deficiency," New England Journal of Medicine, vol. 357, no. 3, pp. 266-281, 2007.

[26] C. J. Rosen, "Clinical practice. Vitamin D insufficiency," The New England Journal of medicine, vol. 364, no. 3, pp. 248-254, 2011.

[27] A. M. Wallace, S. Gibson, A. de la Hunty, C. LambergAllardt, and M. Ashwell, "Measurement of 25-hydroxyvitamin $\mathrm{D}$ in the clinical laboratory: current procedures, performance characteristics and limitations," Steroids, vol. 75, no. 7, pp. 477$488,2010$.

[28] M. Kjaergaard, A. E. Eggen, E. B. Mathiesen, and R. Jorde, "Association between headache and serum 25-hydroxyvitamin D, the tromso study: tromso 6," Headache, vol. 52, no. 10, pp. 1499-1505, 2012.

[29] H. L. O’Brien, A. D. Hershey, M. A. Kabbouche et al., "Prevalence of vitamin D deficiency among pediatric patients with recurrent headaches," Headache, vol. 50, supplement 1, p. S23, 2010.

[30] J. C. Krusz, J. P. Albright, and J. Cagle, "Vitamin D levels in migraine and headache patients compared to patients with pain disorders," Headache, vol. 50, pp. S24-S25, 2010.
[31] G. Loncar, B. Bozic, S. Dimkovic et al., "Association of increased parathyroid hormone with neuroendocrine activation and endothelial dysfunction in elderly men with heart failure," Journal of Endocrinological Investigation, vol. 34, no. 3, pp. e78e85, 2011.

[32] G. Rashid, J. Bernheim, J. Green, and S. Benchetrit, "Parathyroid hormone stimulates the endothelial nitric oxide synthase through protein kinase A and C pathways," Nephrology Dialysis Transplantation, vol. 22, no. 10, pp. 2831-2837, 2007.

[33] K. V. Knutsen, M. Brekke, S. Gjelstad, and P. Lagerløv, "Vitamin $\mathrm{D}$ status in patients with musculoskeletal pain, fatigue and headache: a cross-sectional descriptive study in a multi-ethnic general practice in Norway," Scandinavian Journal of Primary Health Care, vol. 28, no. 3, pp. 166-171, 2010. 


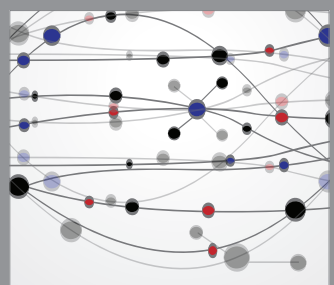

The Scientific World Journal
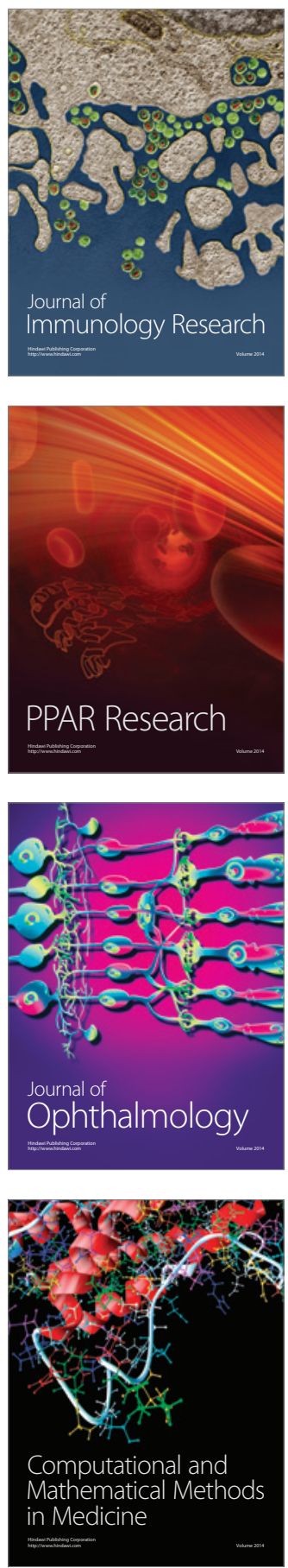

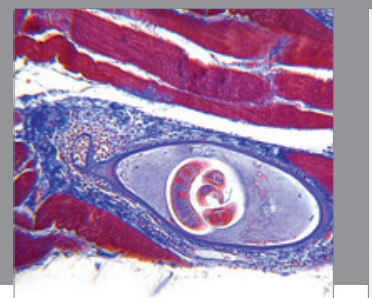

Gastroenterology

Research and Practice
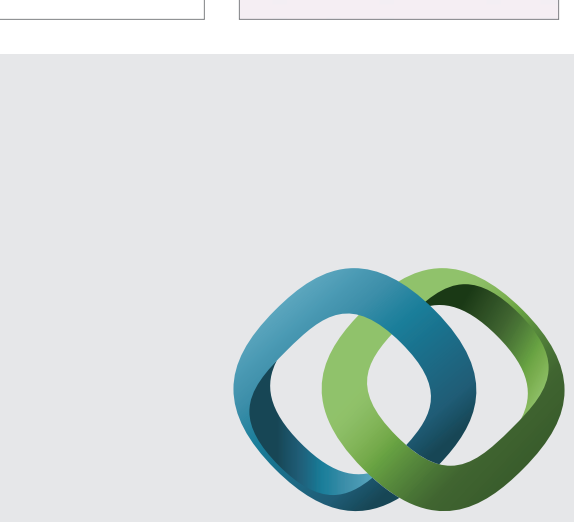

\section{Hindawi}

Submit your manuscripts at

http://www.hindawi.com
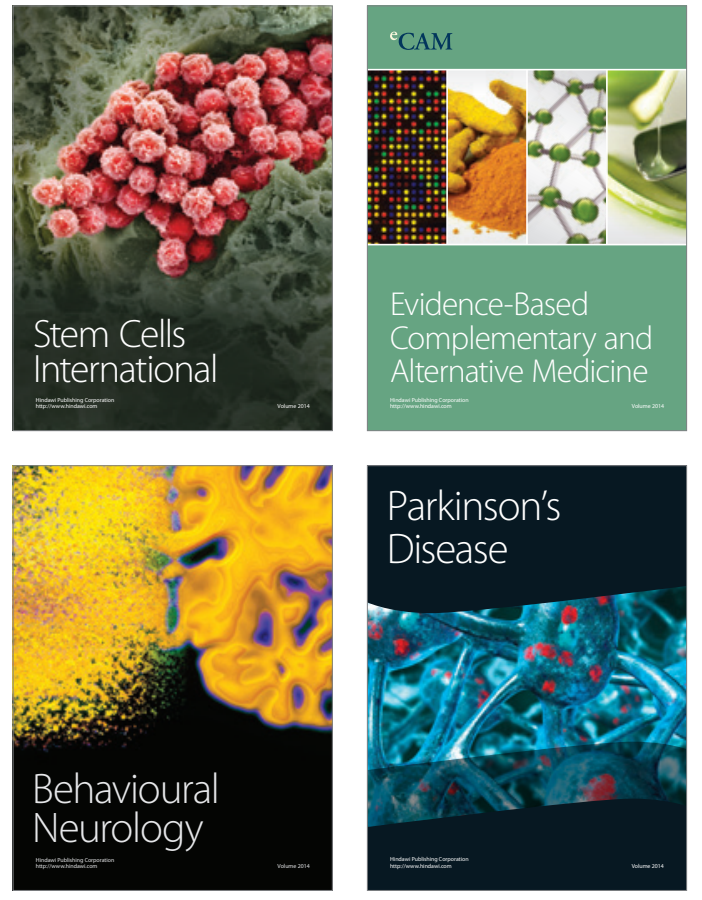
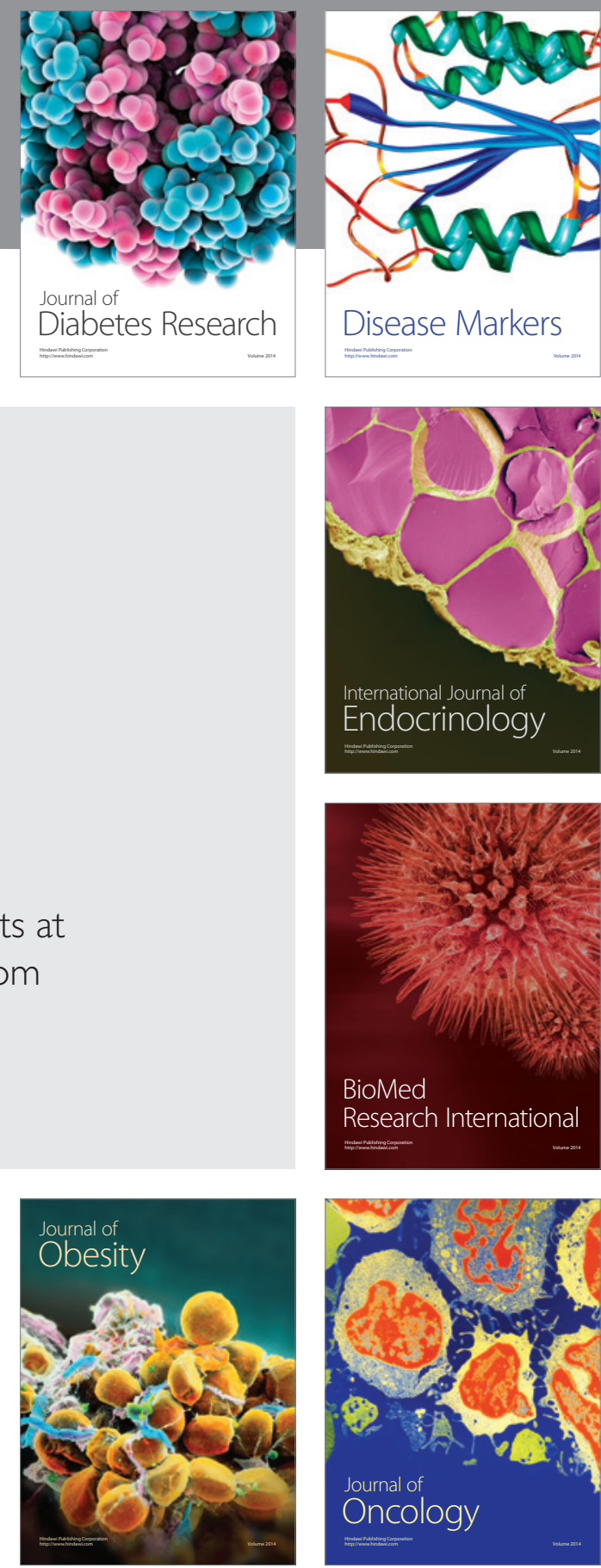

Disease Markers
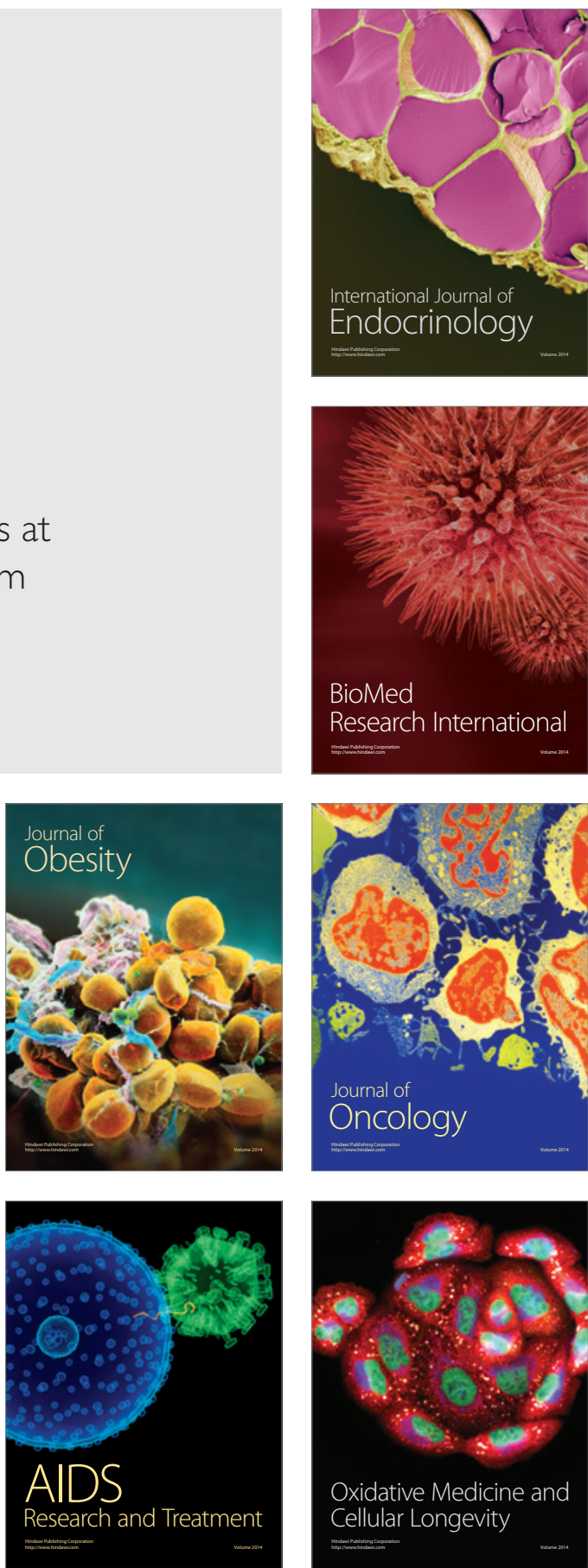